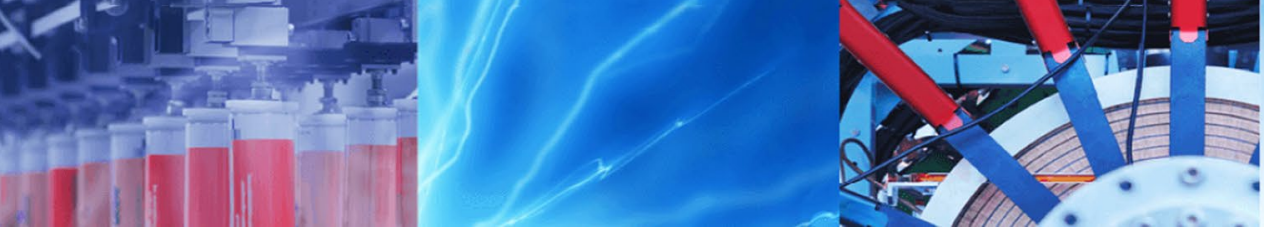

Research Article

\title{
Statistical optimization for determination of trace amounts of RDX in matrix of HMX using GC-ECD
}

\author{
Hamid Reza Pouretedal' · Sajjad Damiri ${ }^{1}$. Ali Reza Sharifi ${ }^{1}$
}

(c) Springer Nature Switzerland AG 2019

\begin{abstract}
1,3,5,7-Tetranitro-1,3,5,7-tetrazocane (HMX) is one of the most powerful military explosives that is produced by means of Bechmann method. Simultaneous, 1,3,5-rinitroperhydro-1,3,5-triazine (RDX) as a by-product is produced in this method that affect on the purity and sensitivity of HMX. Using a simple and fast technique is important for determination of trace amounts of RDX in the HMX matrix. The technique of gas chromatography-electron capture detector (GC-ECD) was proposed for these reasons. Because the presence of several parameters in the proposed technique, the experimental design methods of factorial and central composite were used for the experiments of screening and optimization, respectively. The parameters of oven programming, injection volume, injection temperature, carrier gas flow rate, and detector temperature were used in experiments of screening. The analysis of variance and Pareto plots showed that the injection temperature and carrier gas flow rate must be optimized among the parameters. After the screening and optimization of the studied parameters, the selected conditions were oven programming $10^{\circ} \mathrm{C} \mathrm{min}^{-1}$, injection volume $1 \mu \mathrm{L}$, injection temperature $250{ }^{\circ} \mathrm{C}$, carrier gas $\left(\mathrm{N}_{2}\right)$ flow rate $3 \mathrm{~mL} \mathrm{~min}{ }^{-1}$, and detector temperature $300^{\circ} \mathrm{C}$. The calibration curve and detection limit of the optimized method were 10-90 and $1.8 \mathrm{mg} \mathrm{L}^{-1}$, respectively, of RDX in matrix of HMX. The relative standard deviation of the measurement was $1.89 \%$. Finally, the RDX recovery percentages in HMX matrix in the three spiked samples were also calculated.
\end{abstract}

Keywords Statistical optimization $\cdot$ Electron capture detector $\cdot \mathrm{RDX} \cdot \mathrm{HMX} \cdot$ Experimental design

\section{Introduction}

Due to increased attention to insensitive ammunition to improve safety and high performance, there is a growing demand for insensitive explosives [1]. 1,3,5,7-Tetranitro1,3,5,7-tetrazocane, commonly known as HMX, is one of the most powerful military explosives that is produced by means of Bechmann method. This explosive has a high detonation velocity, heat and pressure and is widely used in plastic explosives and solid propellants [2]. However, HMX particles have limitations in application as insensitive ammunition. The high mechanical sensitivity and weak adhesion properties with other materials in polymer bonded explosives (PBXs) are subject to these restrictions [3]. To obtain insensitive HMX particles with lower sensitivity to shock wave and mechanical stimuli, many studies have been done on the effect of particle size, their shape, removal of HMX-associated impurities through crystallization or polymer-bonding $[4,5]$. One of the impurities that is produced in the production process of HMX is always 1,3,5-rinitroperhydro-1,3,5-triazine or RDX. The RDX amount is less than $0.2 \%$ by weight in an insensitive HMX. Therefore, for the production of high-purity HMX, it is necessary to measure amounts of less than $0.2 \%$ wt. RDX.

In the US military standard [6], a liquid chromatography and X-ray diffraction methods for the detection and

\footnotetext{
$\triangle$ Hamid Reza Pouretedal, pouretedal@gmail.com; HR_POURETEDAL@mut-es.ac.ir; Sajjad Damiri, s_damiri@mut-es.ac.ir; Ali Reza Sharifi, ali.sharifi516@yahoo.com | 'Department of Chemistry, Faculty of Science, Malek-ashtar University of Technology, Shahin-Shahr, Isfahan, Islamic Republic of Iran.
} 
measurement of RDX is presented. However, there is always a need for a simple and rapid method for detecting and determining RDX in HMX tissue. Referring to the history of explosives, it is clear that measuring trace amounts of RDX in HMX matrix is done in a variety of ways. Grindlay [7] measured the RDX in HMX using the infrared spectrophotometer method at the British Defense Research Institute. The wavelength used was $1590 \mathrm{~cm}-1$. Mattos et al. [8] used the FT-IR (Fourier-transform infrared spectroscopy) method in the near (NIR) and mid (MIR) IR regions, and measured RDX in HMX and compared the results by high performance liquid chromatography (HPLC) method. Uzer et al. [9] were able to measure the RDX in HMX using the spectrophotometer in the visible region. The detection limit of the method was $0.18 \mathrm{~g} \mathrm{ml}^{-1}$. Zou et al. [10] devised a method for measuring the RDX impurity in HMX using a FT-NIR device, and they were able to obtain a small amount by using a chemometric and the partial least squares method.

Using GC to identify and measure explosives is limited due to the high melting point, low vapor pressure and thermal instability of these materials. However, Hable [11] using extraction and injection, could analyze the low amounts of RDX. He used injection ports that were deactivated glasses, and the materials had a little thermal decomposition on the surface. Krichner et al. [12] used the GC-ECD method to analyze some of the explosives, including RDX. The column used was capillary type of $\mathrm{cp}$ sil 8. The detector temperature was $320^{\circ} \mathrm{C}$ and the nitrogen gas flow rate was $60 \mathrm{ml} \mathrm{min}{ }^{-1}$. The device was also used in splitless mode. Protectants such as $d$-sorbitol have been used to eliminate the peak tailing. In these methods, since the device is in a splitless mode, it should be used two columns. The first pre-column has a length of $1 \mathrm{~m}$ to increase the transfer rate of solutes from the inlet to the column. The injection port is also of glass type and should be replaced after every 10 analyses [12]. Douse [13] presented a method for detecting traces of explosives like RDX and TNT at the low nanogram level using GC-ECD and capillary column. The injection temperature was not adequate for HMX. Walsh et al. [14] determined nitroaromatic, nitramine, and nitrate ester explosives in water using solid-phase extraction and acetonitrile solvent and GC-ECD. Method detection limits ranged from 0.04 to $0.4 \mu \mathrm{g} / \mathrm{L}$. Deactivated direct injection uniliner was used in GC instrumentation. Walsh [15] determined nitroaromatic, nitramine, and nitrate ester explosives in soil by gas chromatography and an electron capture detector. Method detection limits were around $3 \mu \mathrm{g} / \mathrm{kg}$ for RDX, $25 \mu \mathrm{g} / \mathrm{kg}$ for HMX, and between 10 and $40 \mu \mathrm{g} /$ $\mathrm{kg}$ for the nitrate esters (NG and PETN). Waddell et al. [16] determined nitroaromatic and nitramine explosives from a PTFE wipe using thermal desorption-gas chromatography with electron-capture detection. The explosives were desorbed by thermal desorption system and sent to a cooled injection system. A dual column and dual ECD was used to confirm analysis of the explosives desorbed. Limits of detection less than $4 \mathrm{ng}$ obtained for each explosive.

The investigated methods are not particularly sensitive to RDX measurements in the HMX matrix. Therefore, the aim of this research was to measure trace amounts of RDX in HMX explosive tissue using a simple and fast gas chromatography and ECD detector. The GC method has an improved chromatographic resolution than HPLC method and utilizing of GC instrumentation is most commonly in environmental labs. The above methods need attention to instrument maintenance because of frequent changes of deactivated injection port liner. As a result, the GC must be calibrated after every change. Another point of our work is the same carrier and makeup gases.

The HMX explosive usually has an RDX of less than $0.2 \%$ by weight. The HP- 5 column is the most commonly used. The column has polarity equivalent to cp-sil-8. These columns have the most separation for nitramine compounds.

Design of experiment methods (DOE) such as multivariate design can be used for predicted variation of several variables in an experimental design. The obtained results are used to drive mathematical models for prediction of the dependent variables from independent variables. Also, the optimized experimental conditions and the interactions between variables can be resulted from the mathematical models [17]. The DOE technique is used for study and optimization the effective variables on the response of an experiment. The decrease the number of experiments is also an advantage for DOE technique. There are several methods in DOE technique for example central composite design (CCD). This method provides high quality predictions in investigation linear, quadratic and interaction effects of variables that are effective on a process $[18,19]$.

\section{Experimental}

\subsection{Materials}

Dinitrobenzene (DNB) as internal standard [20], the solvents of acetonitrile and acetone, all from Merck, were used with highest analytical purity. The explosives RDX and $\mathrm{HMX}$ were synthesized in research laboratory. Each of these materials was then purified in pure acetone (Merck). The purification method was re-crystallization. The amount of purification is 3 times. Finally, the purity of both materials was determined by HPLC apparatus, which was $99.9 \%$. These high purity materials are prepared by calibration solutions. 


\subsection{GC-ECD instrumentation}

The RDX analysis in HMX matrix was performed on an Agilent Technology gas chromatography system 6890A, equipped with an Auto Sampler 7693 (Agilent Technology), and an ECD. Data were acquired and processed using Agilent Open LAB Chromatography Data System (CDS) Chemstation Edition for integrated peak areas, peak heights, and elution and analysis times. The HP-5 column with a maximum temperature capacity of $450^{\circ} \mathrm{C}$, $15 \mathrm{~m} \times 250 \mu \mathrm{m} \times 0.1 \mu \mathrm{m}$ dimension, splitless injection and $\mathrm{N}_{2}$ gas carrier were used in all experiments.

\subsection{Screening and optimization experiments}

To prepare the stock solutions, RDX and HMX materials with purity of $99.9 \%$ were dried in an oven with temperature of $100^{\circ} \mathrm{C}$. The stock solution of $1000 \mathrm{mg} \mathrm{L}^{-1} \mathrm{RDX}$ was prepared, and then the diluted solutions (10-90 $\left.\mathrm{mg} \mathrm{L}^{-1}\right)$ were prepared from the stock solution. The standard material of dinitrobenzene ( $100 \mathrm{mg} \mathrm{L}^{-1}$ in acetonitrile) was used as internal standard. This solution was added to the sample solutions, so that in the final obtained solutions, the concentration of dinitrobenzene was $20 \mathrm{mg} \mathrm{L}^{-1}$.

Given that the main texture of the sample is the HMX matrix, there should also be HMX within the calibration solutions of RDX (although the calibration curve is plotted relative to the RDX concentration). HMX stock solution was prepared with a concentration of $20 \mathrm{~g} \mathrm{~L}^{-1}$ of pure $\mathrm{HMX}$ in acetonitrile. The concentration of HMX in the final solutions was $8 \mathrm{~g} \mathrm{~L}^{-1}$.

\section{Results and discussion}

\subsection{Experiments of screening}

The design and analysis of experiments data were by using the Minitab 17.1 software. Based on the experimental conditions, a $2^{5}$ factorial design was used for screening the five quantitative factors in order to identify the most critical factors for optimization. The factors were the oven programming, injection volume, injection temperature, carrier gas flow rate, and detector temperature. A full factorial design by using 32 experiments was used that allows for better estimation of the effects of the experimental factors on the response(s) and therefore, better selection of the significant factors for optimization [21,22]. The studied factors and their levels are presented in Table 1.

The oven programming was as follows. The start temperature $100{ }^{\circ} \mathrm{C}$ for $2 \mathrm{~min}$, the initial end temperature $200^{\circ} \mathrm{C}$, the temperature ramping (rate) was varied according to the Table 1 to a final temperature of $250^{\circ} \mathrm{C}$ and held
Table 1 Factors and their levels used in the screening experiments

\begin{tabular}{lllr}
\hline Factor & Symbol & -1 & +1 \\
\hline Oven programming $\left({ }^{\circ} \mathrm{C} \mathrm{min}\right.$ & -1 \\
Injection volume $(\mu \mathrm{L})$ & A & 10 & 15 \\
Injection temperature $\left({ }^{\circ} \mathrm{C}\right)$ & $\mathrm{B}$ & 1 & 2 \\
Carrier gas $\left(\mathrm{N}_{2}\right.$ gas) flow rate $\left(\mathrm{mL} \mathrm{min}^{-1}\right)$ & $\mathrm{C}$ & 200 & 250 \\
Detector temperature $\left({ }^{\circ} \mathrm{C}\right)$ & $\mathrm{E}$ & 1.5 & 3 \\
\hline
\end{tabular}

for $5 \mathrm{~min}$. All injections were done in the splitless mode $(1: 6)$. The responses studied for these set of experiments were the peak area of $\operatorname{RDX}\left(\mathrm{Y}_{1}\right)$ and the resolution factor $(\mathrm{R})$ for peaks of RDX and $\mathrm{HMX}\left(\mathrm{Y}_{2}\right)$. The $\mathrm{R}$ was calculated using the following equation:

$R=\left[2\left(t_{2}-t_{1}\right) /\left(w_{1}+w_{2}\right)\right]$

where $t_{1}$ and $t_{2}$ are the migration times of RDX peak and HMX peak and $w_{1}$ and $w_{2}$ are the baseline peak widths, respectively.

The Pareto chart of effects tool was used for statistically study the critical factors on the selected responses [23]. The Pareto chart is an important statistical tool useful for visual identification of significant and less significant factors in a set of multivariate experiments. The $t$-value of an absolute effect in terms of standard deviations was used in scales experimental effects. A factor was known as a significant parameter at $95 \%$ confidence level when experimental factor(s) was extends beyond the t-limit value (the vertical dash-lines). The Pareto charts of responses of peak area and the resolution factor for the test of significance of the screening factors are presented in Fig. 1.

The Fig. 1 based on these two responses shows that the injection temperature $(C)$ and the carrier gas flow rate (D) were the most critical factors, as they were the factors that significantly affected peak area and peak resolution. Also, the analysis of variance (ANOVA) test was used for the screening experiments in order to the selection of the factors that significantly affected the responses. The obtained results of F-value and $P$ value are collected in Table 2 .

The Fisher ratios (F-value) were used for assessing the statistical significance [24]. According to the ANOVA analysis (Table 2), the F-values of 16.33 and 7.12 for $Y_{1}$ response and 13.31 and 18.77 for $Y_{2}$ response, respectively, for factors of the injection temperature and carrier gas flow rate show the significance effect on the variation in the responses. Also, the related $P$-value is used to judge whether F-ratio is large enough to indicate statistical significance. A $P$-value more than 0.05 indicated that the factor could not be considered statistically significant. The $P$-values for the factors of oven programming, injection volume and detector temperature are greater than 0.05 
Fig. 1 Pareto chart for effects of the selected factors on peak area of $\operatorname{RDX}\left(\mathrm{Y}_{1}\right)$ and the resolution factor of peaks of RDX and $\operatorname{HMX}\left(\mathrm{Y}_{2}\right)$
Table 2 The ANOVA test results for the screening experiments

\section{Pareto Chart of the Effects}

(response is $\mathrm{Y} 1 ; \alpha=0.15$; only 30 effects shown)

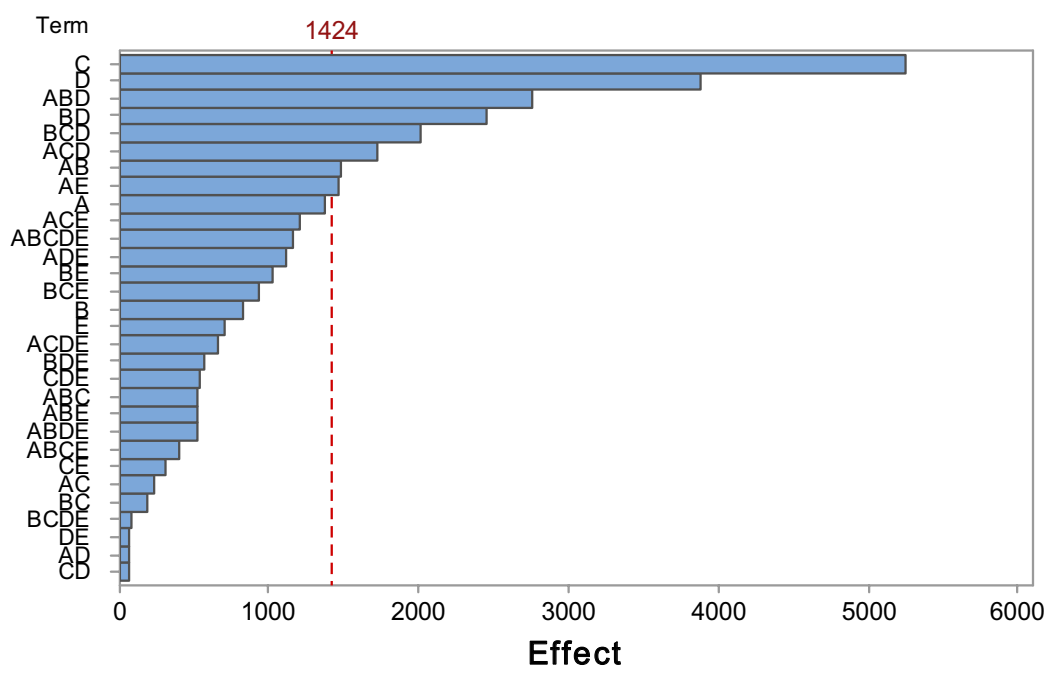

Lenth's PSE $=915.562$
Pareto Chart of the Effects (response is $\mathrm{Y} 2 ; \alpha=0.15$; only 30 effects shown)

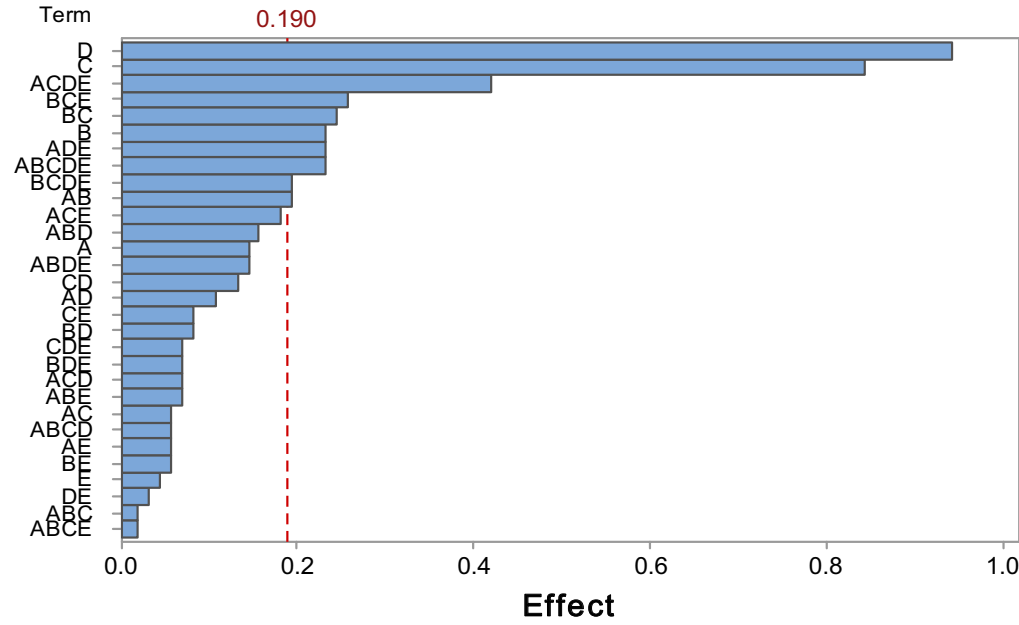

Lenth's PSE $=0.121875$

\begin{tabular}{|c|c|c|c|c|c|}
\hline \multirow[t]{2}{*}{ Factor } & \multirow[t]{2}{*}{ Symbol } & \multicolumn{2}{|l|}{$\mathrm{Y}_{1}$} & \multicolumn{2}{|l|}{$\mathrm{Y}_{2}$} \\
\hline & & F-value & $P$-value & F-value & $P$-value \\
\hline Oven programming $\left({ }^{\circ} \mathrm{C} \min ^{-1}\right)$ & A & 0.74 & 0.398 & 0.27 & 0.607 \\
\hline Injection volume $(\mu \mathrm{L})$ & B & 0.26 & 0.611 & 0.71 & 0.406 \\
\hline Injection temperature $\left({ }^{\circ} \mathrm{C}\right)$ & $\mathrm{C}$ & 16.33 & 0.000 & 13.31 & 0.001 \\
\hline Carrier gas $\left(\mathrm{N}_{2}\right.$ gas) flow rate $\left(\mathrm{mL} \mathrm{min}{ }^{-1}\right)$ & $\mathrm{D}$ & 7.12 & 0.012 & 18.77 & 0.000 \\
\hline Detector temperature $\left({ }^{\circ} \mathrm{C}\right)$ & $\mathrm{E}$ & 0.19 & 0.667 & 0.02 & 0.876 \\
\hline
\end{tabular}


for both responses and mean consequently that these factors in the screening experiments have not statistical significance on the responses [25].

\subsection{Optimization of experiments}

The results of experiments screening showed that the parameters of injection temperature and carrier gas flow rate indicate two affect factors on the response data. Therefore, in the second step, a central composite design (CCD) response surface method was applied for optimization of selected factors while the other factors were fixed (Table 1). A two-level factorial design with a star design and center points is used in CCD method $[26,27]$. A central composite design is a $2^{\mathrm{k}}$ ( $\mathrm{k}$ is the number of factors) full factorial to which the central point and the star points are added. It is expected that the obtained responses to be in the experimental domain of the response surface in the optimized conditions.

Table 3 shows the experimental levels for the factors used in the optimization experiments. The Minitab program was applied for CCD method and fourteen experimental runs were as experimental. The peak area of $\operatorname{RDX}\left(\mathrm{Y}_{1}\right)$ and resolution factor $\left(\mathrm{R}_{\mathrm{s}}\right)$ for peaks of RDX and $\operatorname{HMX}\left(\mathrm{Y}_{2}\right)$ were determined experimentally for each run prior to modelling with the software. The designed conditions of analysis defined by the software for our investigations and the related experimental results are given in Table 3. All experiments were performed in the fixed conditions of; oven programming (A) of $10^{\circ} \mathrm{C} \mathrm{min}^{-1}$, injection volume (B) of $1.0 \mu \mathrm{L}$, and detector temperature (E) of $300.0^{\circ} \mathrm{C}$. Also, The experimental design were applied in the injection temperature $\left({ }^{\circ} \mathrm{C}\right)$ interval of $200.0 \leq \mathrm{C} \leq 250.0^{\circ} \mathrm{C}$ and carrier gas $\left(\mathrm{N}_{2}\right.$ gas) flow rate range of $1.5 \leq \mathrm{D} \leq 3.0 \mathrm{~mL} \mathrm{~min} \mathrm{~m}^{-1}$.

The mathematical relationship of the two responses of $Y_{1}$ and $Y_{2}$ on the mentioned independent variables can be approximated by the statistical analyses performed by use of multiple regressions and analysis of variances (ANOVA). The sum of squares of the errors, F-values, $P$-values and the regression equations were obtained by Minitab 17.1 software and collected in Tables 4 and 5 . As seen, the $P$-values are $<0.05$ for studied factors that can influence significantly the overall results. The sign of optimized factors of injection temperature $(C)$ and carrier gas flow rate (D) is positive for peak area while they are negative for resolution factor. In the other word, the peak area of RDX is increased with increasing of injection temperature and carrier gas flow rate. In contrast, the resolution factor of RDX peak and HMX peak is decreased with addition of these variable factors. The response factors or the $Y_{1}$ and $\mathrm{Y}_{2}$ in the interval of our experiment design can be calculated from Eqs. (2) and (3).

$$
\begin{aligned}
\text { Peak area }\left(Y_{1}\right)= & 4600+38.3 C+2300 D \\
& -557 D * D+20.61 C * D
\end{aligned}
$$

Resolution factor $\left(Y_{2}\right)=16.442-0.02806 C$

$$
-2.071 D+0.2017 D * D
$$

The ANOVA results and the estimated regression coefficients for the peak area $\left(Y_{1}\right)$ and resolution factor $\left(\mathrm{Y}_{2}\right)$ are presented in Tables 4 and 5, respectively. In the validation of models, experimental results and the predicted values obtained using Eqs. 2 and 3 match the

\begin{tabular}{|c|c|c|c|c|c|c|}
\hline Run order & $\begin{array}{l}\text { Injection tempera- } \\
\text { ture }\left({ }^{\circ} \mathrm{C}\right)\end{array}$ & 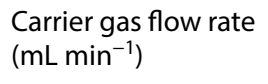 & Exp. peak area $\left(\mathrm{Y}_{1}\right)$ & Predicted $Y_{1}$ & $\begin{array}{l}\text { Exp. resolution } \\
\text { factor }\left(\mathrm{Y}_{2}\right)\end{array}$ & Predicted $\mathrm{Y}_{2}$ \\
\hline 1 & 225.0 & 1.23 & 20,256 & $20,683.4$ & 8.0 & 7.95259 \\
\hline 2 & 225.0 & 2.25 & 25,726 & $26,011.5$ & 6.4 & 6.49231 \\
\hline 3 & 225.0 & 3.31 & 30,145 & $30,086.9$ & 5.4 & 5.48587 \\
\hline 4 & 225.0 & 2.25 & 25,745 & $26,011.5$ & 6.5 & 6.49231 \\
\hline 5 & 225.0 & 2.25 & 25,745 & $26,011.5$ & 6.5 & 6.49231 \\
\hline 6 & 189.6 & 2.25 & 22,725 & $23,017.5$ & 7.5 & 7.48425 \\
\hline 7 & 260.4 & 2.25 & 29,125 & $29,005.6$ & 5.3 & 5.50037 \\
\hline 8 & 250.0 & 1.50 & 24,315 & $24,104.3$ & 6.9 & 6.77648 \\
\hline 9 & 250.0 & 3.00 & 31,394 & $31,526.6$ & 5.1 & 5.03224 \\
\hline 10 & 225.0 & 2.25 & 25,745 & $26,011.5$ & 6.5 & 6.49231 \\
\hline 11 & 200.0 & 3.00 & 26,678 & $26,519.4$ & 6.5 & 6.43506 \\
\hline 12 & 200.0 & 1.50 & 21,145 & $20,643.1$ & 8.0 & 8.17930 \\
\hline 13 & 225.0 & 2.25 & 26,456 & $26,011.5$ & 6.6 & 6.49231 \\
\hline 14 & 225.0 & 2.25 & 26,456 & $26,011.5$ & 6.6 & 6.49231 \\
\hline
\end{tabular}
experimental values reasonably well with $\mathrm{R}-\mathrm{Sq}$ of $99.38 \%$

Table 3 Central composite design (CCD) in optimization of experiments 
Table 4 Analysis of variance of CCD method: Peak area and resolution versus injection temperature and carrier gas flow rate

\begin{tabular}{lcrrrrr}
\hline Source & Degree of freedom & F-value & $\begin{array}{c}P \text {-value } \\
\text { Peak area }\end{array}$ & $\begin{array}{l}\text { Degree of } \\
\text { freedom }\end{array}$ & F-value & $P$-value \\
& Resolution factor & & & \\
\hline Model & 5 & 256.96 & 0.000 & 3 & 244.14 & 0.000 \\
Blocks & 1 & 5.39 & 0.049 & & & \\
Linear & 2 & 632.96 & 0.000 & 2 & 362.74 & 0.000 \\
Injection tem., C & 1 & 365.23 & 0.000 & 1 & 284.95 & 0.000 \\
Carrier gas flow rate, D & 1 & 900.68 & 0.000 & 1 & 440.53 & 0.000 \\
Square & 1 & 7.42 & 0.026 & 1 & 6.92 & 0.025 \\
D*D & 1 & 7.42 & 0.026 & 1 & 6.92 & 0.025 \\
2-way interaction & 1 & 6.09 & 0.039 & & & \\
C*D & 1 & 6.09 & 0.039 & & & \\
Error & 8 & & & 10 & & \\
Lack-of-fit & 4 & 1.33 & 0.395 & 6 & 6.24 & 0.049 \\
Pure error & 4 & & & 4 & & \\
Total & 13 & & & 13 & & \\
\hline
\end{tabular}

Table 5 Estimated regression coefficients for the peak area $\left(Y_{1}\right)$ and resolution factor $\left(\mathrm{Y}_{2}\right)$

\begin{tabular}{lllll}
\hline Term & Coef $^{\mathrm{a}}$ & SE Coef $^{\mathrm{b}}$ & $\mathrm{t}^{\mathrm{c}}$ & $\mathrm{p}^{\mathrm{d}}$ \\
\hline Peak area & & & & \\
$\quad$ Constant & 26,012 & 106 & 244.39 & 0.000 \\
$\quad$ Injection tem., C & 2117 & 111 & 19.11 & 0.000 \\
Carrier gas flow rate, D & 3325 & 111 & 30.01 & 0.000 \\
D*D & -313 & 115 & -2.72 & 0.026 \\
C*D & 386 & 157 & 2.47 & 0.039 \\
Resolution factor & & & & \\
Constant & 6.4923 & 0.0399 & 162.63 & 0.000 \\
Injection tem., C & -0.7014 & 0.0416 & -16.88 & 0.000 \\
Carrier gas flow rate, D & -0.8721 & 0.0416 & -20.99 & 0.000 \\
D*D & 0.1135 & 0.0431 & 2.63 & 0.025 \\
\hline
\end{tabular}

${ }^{\mathrm{a}}$ Coefficient

${ }^{\mathrm{b}}$ Standard error of the coefficient

$c^{t}$ test

${ }^{d} p$ value

and R-Sq (adj) of $98.99 \%$ for response $Y_{1}$, and with R-Sq of $98.65 \%$ and R-Sq (adj) of $98.25 \%$ for response $Y_{2}$. The statistical significance of the ratio adjusted mean square (adj MS) due to the regression and adjusted mean square of residual error were tested using analysis of variance (ANOVA). The model Fisher ratios (F-value) of 256.96 for $Y_{1}$ and 244.14 for $Y_{2}$ indicate that most of the variation in the response can be described by the regression equation. Also, the $P$-value for the two regressions of $Y_{1}$ and $\mathrm{Y}_{2}$ obtained $P=0.000$ were lower than 0.05 and means consequently that all terms in the regression equations have significant correlation with the response variables $[28,29]$.

\section{SN Applied Sciences}

The contour plots of peak area and resolution factor versus injection temperature and carrier gas flow rate are shown in Fig. 2. However, the contour plots also indicate that for obtaining the high sensitivity for the RDX peak and a suitable resolution for RDX and HMX peaks, the optimized values for carrier gas flow rate and injection temperature are $3 \mathrm{~mL} \mathrm{~min}{ }^{-1}$ of $\mathrm{N}_{2}$ gas and $250{ }^{\circ} \mathrm{C}$, respectively.

The chromatogram of a sample contains $90 \mathrm{mg} \mathrm{L}^{-1}$ RDX in HMX matrix in optimized conditions of oven programming $10{ }^{\circ} \mathrm{C} \mathrm{min}^{-1}$, injection volume $1 \mu \mathrm{L}$, injection temperature $250^{\circ} \mathrm{C}$, carrier gas flow rate $3 \mathrm{~mL} \mathrm{~min}^{-1}$, and detector temperature $300^{\circ} \mathrm{C}$, is shown in Fig. 3. The calibration curve for determination of trace amounts of RDX (10-90 $\mathrm{mg} \mathrm{L}^{-1}$ ) in HMX matrix by using GC-ECD method in optimization conditions is also presented in Fig. 4. The equation of linear curve is as follows:

$Y=0.0683 X-0.2721$

where $Y$ is the area ratio of RDX peak to DNB peak and $X$ is the concentration of $\mathrm{RDX}\left(\mathrm{mg} \mathrm{L}^{-1}\right)$. The regression $\left(\mathrm{R}^{2}\right)$ of the curve is obtained 0.9917 . The relative standard deviation (RSD) of the method for determination of RDX concentration of a sample contains $10 \mathrm{mg} \mathrm{L}^{-1}$ of it was $1.89 \%$. Also, the detection limit $(L O D=3 \mathrm{~s} / \mathrm{m})$ of the proposed procedure is calculated $1.3 \mathrm{mg} \mathrm{L}^{-1}$. The three spiked samples were analyzed for study the precision and accuracy of the proposed method. The obtained data are collected in Table 6. The minimum standard deviation values and the recovery percent values of $93-98 \%$ show the precision and accuracy of the proposed method in optimized conditions. 
Fig. 2 Contour plots of optimized factors (I) peak area and (II) resolution factor
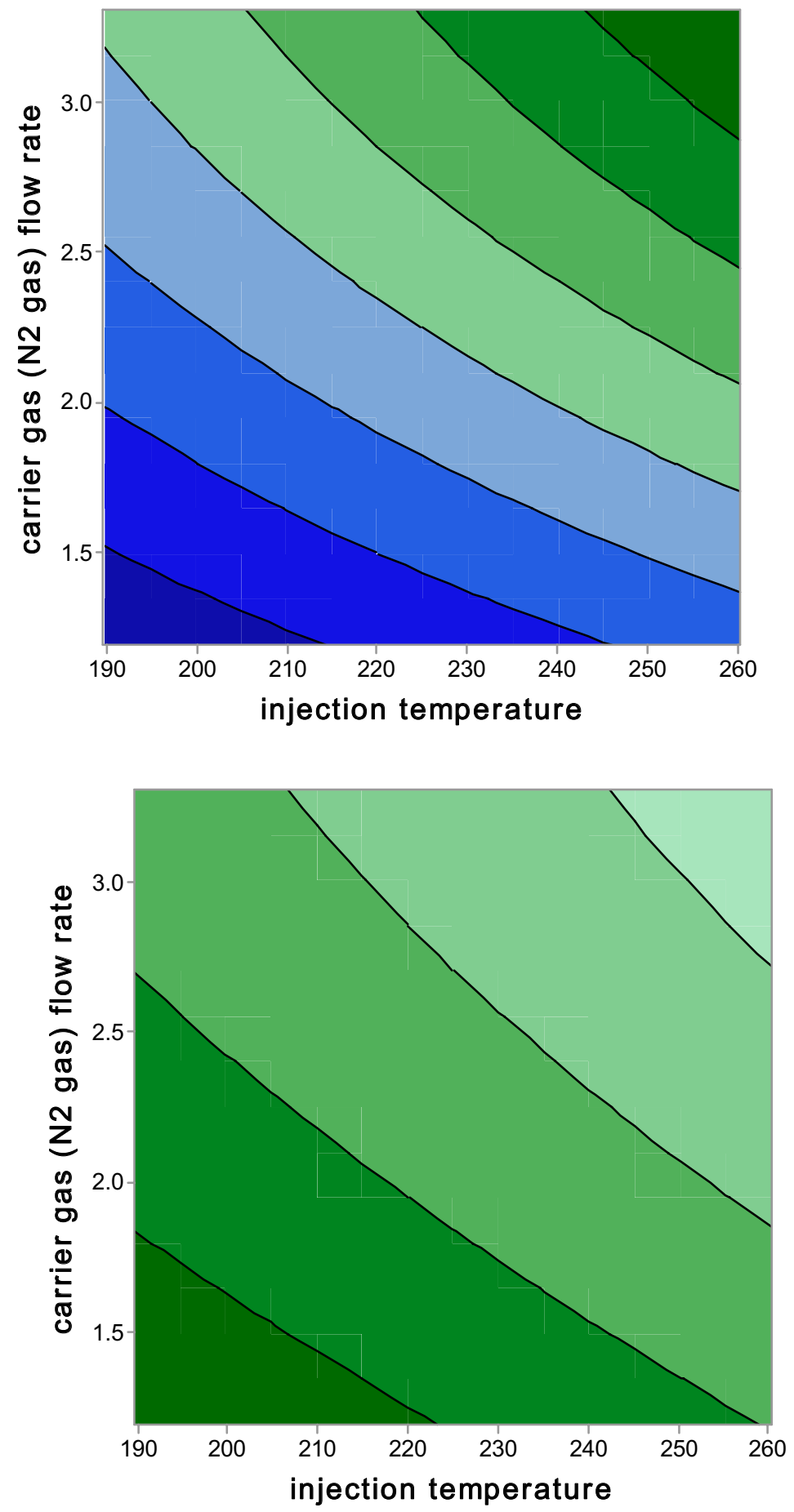

Peak area $(\mathrm{Y} 1)$

$<20000$

$20000-22000$

$22000-24000$

$24000-26000$

$26000-28000$

$28000-30000$

$30000-32000$

$>32000$

\section{Conclusion}

The experimental design methods including factorial design and central composite design are used for selection of significant factors and optimization of them. The design of experiments and optimization of parameters reduce the time and cost in determination of purity of HMX with measurement trace amounts of RDX $(0.2 \%$ w/w) using the technique of gas chromatography-electro capture detector.

Using the normal injection ports is one the advantages of the proposed method. The device with a split mode is also used, which does not require a pre-column. The splitter enters the part of the gas phase in which the specimen is inserted into the column of the muffin. Also, the nitrogen gas is used as a carrier gas that is passed 


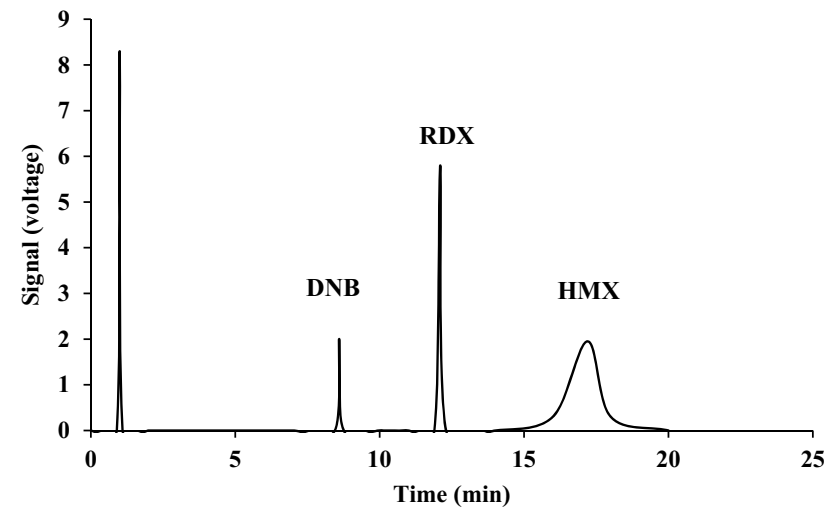

Fig. 3 Chromatogram of a sample contains internal standard of DNB, $90 \mathrm{mg} \cdot \mathrm{L}^{-1} \mathrm{RDX}$ in $\mathrm{HMX}$ matrix $(0.12 \% \mathrm{~W} / \mathrm{V}$ in acetonitrile solvent). The retention times were: DNB $8.6 \mathrm{~min}, \mathrm{RDX} 12.1 \mathrm{~min}$ and HMX 17.2 min

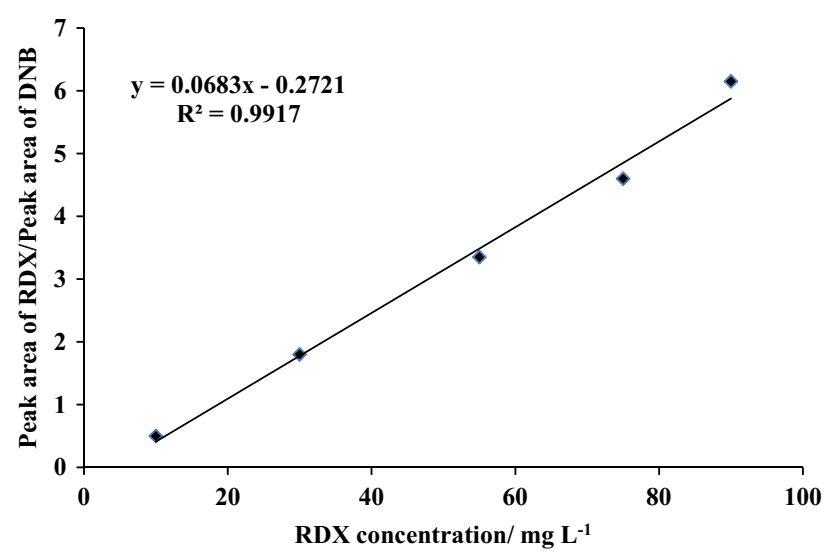

Fig. 4 The calibration curve of determination of RDX (10-90 ppm) in HMX matrix

Table 6 The analysis of spiked samples (RDX in HMX matrix)

\begin{tabular}{lllll}
\hline Sample & $\begin{array}{l}\mathrm{RDX}^{\mathrm{mdded}} \\
\mathrm{mg} \mathrm{L}^{-1}\end{array}$ & $\begin{array}{l}\mathrm{RDX} \\
\text { obtained } \\
\mathrm{mg} \mathrm{L}^{-1}\end{array}$ & $\begin{array}{l}\text { Standard } \\
\text { deviation } \\
(\mathrm{n}=3)\end{array}$ & $\begin{array}{l}\text { Recov- } \\
\text { ery } \\
\text { percent }\end{array}$ \\
\hline 1 & 20.0 & 18.7 & \pm 0.3 & 93.5 \\
2 & 40.0 & 39.2 & \pm 0.4 & 98.0 \\
3 & 60.0 & 58.9 & \pm 0.3 & 98.2 \\
\hline
\end{tabular}

through the ECD detector simultaneously. Therefore, the extra peaks are not appears on the chromatogram.

Acknowledgements We would like to thank the research committee of Malek-ashtar University of Technology (MUT) for supporting this work.

\section{Compliance with ethical standards}

Conflict of interest The authors declare that they have no conflict of interest.

\section{References}

1. Tang P, Jiang ZH, Lu ZH (2012) Analysis of the Key Technicals of Insensitive Munitions, Insensitive Munitions and Energetic Materials Technology Symposium, Las Vegas, NV, USA. May $14-17$, p. 572

2. Liu J, Jiang W, Li FS, Wang LX, Zeng JB, Li Q, Wang Y, Yang Q (2014) Effect of drying conditions on the particle size, dispersion state, and mechanical sensitivities of nano HMX. Propellants Explos Pyrotech 39:30-39

3. Song XL, Wang Y, An CW, Guo XD, Li FS (2008) Dependence of particle morphology and size on the mechnical sensitivity and thermal stability of octahydro-1,3,5,7-tetranitro-1,3,5,7-tetrazocine. J Hazard Mater 159:222-229

4. Zhu Q, Xiao C, Li S, Luo G (2016) Bioinspired fabrication of insensitive HMX particles with polydopamine coating. Propellants Explos Pyrotech 41:1092-1097

5. Niu C, Jin B, Peng R, Yu S, Liu Q (2017) Preparation and characterization of insensitive $\mathrm{HMX} / \mathrm{rGO} / \mathrm{G}$ composites via in situ reduction of graphene oxide. RSC Adv 7:32275-32281

6. "Military Specification" "cyclotetramethylenetetranitramine (HMX)" (1997) MIL-DTL-45444C 11-19

7. Grindlay JW (1972) Determination of hexa hydro 1,3,5-triniro-s-triazine (RDX) in octa hydro-1,3,5,7-tetranitro- $s$ -tetrazocine(HMX) by infrared spectrophotometry. Anal Chem 44:1676-1678

8. Mattos EC, Moreira ED, Dutra RCL, Diniz MF, Ribeiro AP, Iha K (2004) Determination of the HMX and RDX content in synthesized energetic material by HPLC, FT-MIR, and FT-NIR spectrscopies. Quim Nova 27:540-544

9. Uzer A, Ercag E, Apak R (2008) Spectrophotometric determination of cyclotrimethylenetrinitramine (RDX) in explosive mixtures and residues with the Berthelot reaction. Anal Chim Acta 612:53-64

10. Zou Q, Deng G, Guo X, Jiang W, Li F (2013) A green analytical tool for in-process determination of RDX content of propellant using the NIR system. ACS Sustain Chem Eng 1:1506-1510

11. Hable C, Asowata C, Williams K (1991) The determination of nitroaromatics and nitramines in ground and drinking water by widebore capillary gas chromatography. J Chromatogr Sci 29:131-135

12. Kirchner M, Matisová E, Hrouzková S, Húšková R (2007) Fast GC and GC-MS analysis of explosives. Pet Coal 49:72-79

13. Douse JMF (1982) Trace analysis of explosives in Handswab extracts using Amberlite XAD-7 porous polymer beads, silica capillary column gas chromatography with electron-capture detection and thin-layer chromatography. J Chromatogr A 234:415-425

14. Walsh ME (1998) Determination of nitroaromatic, nitramine, and nitrate ester explosives in water using solid-phase extraction and gas chromatography-electron capture detection: comparison with high-performance liquid chromatography. J Chromatogr Sci 36:406-416

15. Walsh ME (2001) Determination of nitroaromatic, nitramine, and nitrate ester explosives in soil by gas chromatography and an electron capture detector. Talanta 54:427-438 
16. Waddell R, Dale DE, Monagle M, Smith SA (2005) Determination of nitroaromatic and nitramine explosives from a PTFE wipe using thermal desorption-gas chromatography with electroncapture detection. J Chromatogr A 1062:125-131

17. Pouretedal HR, Damiri S, Najafi R (2017) Statistical optimization of removal of nitro-body compounds from spent acid of toluene nitration process. Desalin Water Treat 98:161-168

18. Damiri S, Pouretedal HR, Panahi H, Dris A (2017) Statistic optimization and selective separation of RDX and HMX explosives by using binary solvent mixtures of Ethyl acetate/water. Cent Eur J Energ Mater 14:391-402

19. Damiri S, Pouretedal HR, Rahimi Ashjerdi A (2017) Response surface optimization of purification process of cyclotrimethylenetrinitramine explosive via digestion in binary solvent mixtures of acetone/water. Sep Sci Technol 52:478-496

20. Lowre ML (1967) Determination of Hexahydro-1,3,5-trinitro-striazine in octahydro-1,3,5,7-tetranitro-s-tetrazine by Gas Chromatography. J Chromatogr Sci 5:531-532

21. Zubair A, Pappoe M, James LA, Hawboldt K (2015) Development, optimization, validation and application of fastergas chromatography-flame ionization detector method for the analysis of total petroleum hydrocarbonsin contaminated soils. J Chromatogr A 1425:240-248

22. Hibbert DB (2012) Experimental design in chromatography: a tutorial review. J Chromatogr B 910:2-13

23. Groskreutz SR, Weber SG (2016) Graphical method for choosing optimized conditions given a pump pressure and a particle diameter in liquid chromatography. Anal Chem 88:11742-11749
24. Enrique M, García-Montoya E, Miñarro M, Orriols A, Ticó JR, SuñéNegre JM, Pérez-Lozano P (2008) Application of an experimental design for the optimization and validation of a new HPLC method for the determination of vancomycin in an extemporaneous ophthalmic solution. J Chromatogr Sci 46:828-834

25. Pouretedal HR, Damiri S, Shahsavan A (2018) Modification of RDX and HMX crystals in procedure of solvent/anti-solvent by statistical methods of Taguchi analysis design and MLR technique. Def Technol 14:59-63

26. Torkaman R, Asadollahzadeh M, Torab-Mostaedi M (2018) Effects of nanoparticles on the drop behavior in the Oldshue-Rushton extraction column by using central composite design method. Sep Purif Technol 197:302-313

27. Vafaei F, Torkaman R, Moosavian MA, Zaheri P (2018) Optimization of extraction conditions using central composite design for the removal of $\mathrm{Co}$ (II) from chloride solution by supported liquid membrane. Chem Eng Res Des 133:126-136

28. OzAksoy D, Sagol E (2016) Application of central composite design method to coal flotation: modelling, optimization and verification. Fuel 183:609-616

29. Missaoui I, Sayedi L, Jamoussi B, Hassine BB (2009) Response surface optimization for determination of volatile organic compounds in water samples by headspace-gas chromatographymass spectrometry method. J Chromatogr Sci 47:257-262

Publisher's Note Springer Nature remains neutral with regard to jurisdictional claims in published maps and institutional affiliations. 